\title{
EL SÍNODO DE 1600 DE LA DIÓCESIS DE ORIHUELA
}

\author{
JOAQUÍN MARTÍNEZ VALLS \\ Catedrático de Derecho Eclesiástico del Estado
}

\begin{abstract}
SUMARIO: 1.- Introducción. Creación de la Diócesis.
2.- Los Sínodos de la Diócesis de Orihuela. 2,1 Concepto. 2,2 Número de Sínodos.
\end{abstract}

3.- El Sínodo de 1.600. 3,1 Antecedentes. 3,2 Convocatoria y preparación del Sínodo. 3,3 Celebración de las reuniones. 3,4 Contenido de las reuniones y decretos. 3,4,1 Obligaciones de los clérigos en general. 3,4,2 De las personas eclesiásticas en particular. 3,4,3 De los laicos. 3,4,4 De los sacramentos.

a) Penitencia. b) Eucaristía. c) Matrimonio. 3,4,5 Otras disposiciones.

4.- Dificultades para la aplicación y ejecución del Sínodo.

5.- Importancia y proyección universal del Sínodo de 1.600.

6.- Epílogo.

\section{INTRODUCCIÓN}

La diócesis de Orihuela se crea el 14 de julio de 1564, a instancias del rey Felipe II, y por Bula del papa Pío IV, desmembrándola de la de Cartagena ${ }^{1}$. Se pone así fin a los numerosos litigios que enzarzaron a Orihuela y Murcia durante casi doscientos años ${ }^{2}$. Entre las razones más importantes que justificaron esta creación, destacamos el hecho de que políticamente el territorio de la nueva Diócesis pertenecía al Reino de Valencia, Corona de Aragón; y en lo religioso dependía de un Obispo de Castilla. Fue siempre un deseo de los reyes aragoneses que coincidieran los límites políticos con los religiosos. Además la diversidad de

1 MANSILLA, D., 'La reorganización eclesiástica española del siglo XVI. Aragón y Cataluña', en Anthologica Annua, Roma 1956, p. 130. Por cierto que en la nota 145 dice que «fue despachada por el Cardenal de San Clemente,, y que no he tenido la suerte de encontrar en los Archivos Vaticanos». Nosotros hemos encontrado tanto la Bula de erección como la de creación, ambas en preciosos pergaminos, y con la misma fecha «pridie idus julii 1564». Felipe II el 7 de marzo de 1566 urgió que se ejecutara enseguida lo mandado por el Papa. Y el 23 de marzo de ese año tomaba posesión el primer Obispo Don Gregorio Gallo de Andrade.

2 Con razón GEA, Rufino pudo escribir un documentado trabajo que tituló precisamente «El Pleito del Obispado 1383-1664», Orihuela 1900. En mi tesis doctoral inédita «La Reforma Postridentina del Obispo Esteve en la Diócesis de Orihuela», dedico un amplio capítulo a estas cuestiones con el título 'La Diócesis de Orihuela en el s. XVI', pp. 18-124. Véase también MANSILLA, D., artículo citado en nota anterior. $\mathrm{Y}$ el mismo autor hace un breve resumen del problema en el documentado trabajo «Panorama Histórico-geográfico de la Iglesia española en los siglos XV y XVI», en "Historia de la Iglesia en España", obra dirigida por GARCÍA-VILLOSLADA, R., Vol. III-1, Madrid 1980, pp. 18-19, con abundantes notas. 
lenguas y leyes, el hecho de que los diezmos hubiera que entregarlos a un obispo castellano; razón importante fue también el problema de los moriscos, que tanto preocupaba al Rey Prudente, y que el Obispo de Cartagena no podía atender, dada la enorme amplitud de su territorio ${ }^{3}$.

Esta peculiar situación, así como la reciente creación, y quizá el abandono en muchos aspectos, en que había estado esta parte de la antigua y extensísima diócesis cartaginense, exigía a los Obispos cuidados y medidas especiales para atender adecuadamente las necesidades de todo orden de la nueva diócesis. Y en aquella época tenían una enorme trascendencia las Concilios provinciales y los sínodos diocesanos, cuyas celebraciones fueron impulsadas por el Concilio de Trento. No olvidemos, por otra parte, el interés de Felipe II en que se afianzara la religión católica, en una época de tantos problemas que la reforma protestante había suscitado o propiciado en varias regiones de Europa. En España además existía otro grave problema; el que planteaban al Rey los moriscos, especialmente numerosos y no integrados, en esta región. Para todo esto el Rey solicitaba con frecuencia la colaboración y apoyo de los obispos ${ }^{4}$.

\section{LOS SÍNODOS DE LA DIÓCESIS DE ORIHUELA}

\subsection{Concepto}

La palabra 'Sinodo' procede del griego 'Synodeuein' y significa caminar juntos. Equivale al término 'concilium', del latín 'Cumcieo' o sea 'moverse juntos'. En los autores clásicos designaba cualquier asamblea deliberativa o también el lugar donde se celebraba. En los autores eclesiásticos significaba una

3 La nueva Diócesis se crea con el territorio de la Governació d'Oriola, del Reino de Valencia, tal y como había propuesto el comisionado de Felipe II, el deán de Gandía Don Francisco Roca para estudiar el posible territorio de la nueva diócesis, que lleva fecha del 23 de diciembre 1563 , y que el Rey remitió al Papa por medio de su embajador en Roma. Los límites eran desde donde comienza el linde entre Castilla y Valencia, al sur cerca de Orihuela, hasta Busot y Aguas por el Este; Elda y Petrel por el norte, y por el oeste hasta el término de Abanilla exclusive. Además se añadieron Caudete y Ayora, que no pertenecían a la Governació d'Oriola, pero formaban parte del Reino de Valencia y también pertenecían en lo religioso a la Diócesis castellana de Cartagena. En estos territorios regían los Furs de Valencia de 1552. Y la lengua oficial era el valenciano, además de hablarse por gran parte del pueblo y en numerosos lugares. La nueva diócesis pasa a depender de la metropolitana de Valencia; y Cartagena, hasta entonces obispado exento, se adscribe a la metrópoli de Toledo. El territorio de la nueva diócesis se ha mantenido invariable hasta los arreglos y ajustes de 1951, 1954; y, finalmente, el 1 de octubre de 1957, pasan a esta Diócesis los arciprestazgos de Villajoyosa, Jijona y Callosa de Ensarriá - menos Benisa -, que pertenecían a Valencia.

4 Cfr. el amplio y novedoso trabajo de GARCÍA-VILLOSLADA, R. «Felipe II y la Contrarreforma católica», en IDEM «Historia de la Iglesia en España', Vol. III-2º , Madrid 1980, pp. 5106. Por nuestra parte hemos recogido abundante documentación sobre cartas de Felipe II a obispos levantinos interesándose por el problema de los moriscos. Y contestaciones y misivas de los obispos al monarca sobre lo mismo. 
asamblea de obispos, o de un obispo con sus presbíteros, en la que se trataban cuestiones dogmáticas, teológicas y/o disciplinares ${ }^{5}$.

En la historia encontramos sínodos del más diverso tipo, algunos de ellos designados con términos concretos. En la actualidad tenemos asambleas o reuniones de obispos de diverso grado. Para toda la Iglesia Universal existen el Concilio Ecuménico y el Sínodo Episcopal creado a raíz del Concilio Vaticano II, y compuesto por representantes de todas las Conferencias Episcopales y otros designados directamente ${ }^{6}$. También existen los Concilios particulares que pueden ser de todas las Iglesias o Diócesis de la misma Conferencia Episcopal, y se llaman 'Plenarios'; o Provinciales, si se reúnen los Obispos de una provincia Eclesiástica, presididos por el Metropolitano. Han tenido hace siglos, y vuelven a tener ahora, en la Iglesia una gran importancia para el desarrollo del derecho particular, que tanto auge está tomando otra vez después del Vaticano I $^{7}$.

Una descripción de lo que es en la actualidad un Sínodo Diocesano la encontramos en el mismo Código de Derecho Canónico: «una asamblea de sacerdotes y de otros fieles de una iglesia particular que prestan su ayuda al Obispo para bien de toda la comunidad diocesana» ${ }^{8}$.

5 Una exposición histórico-jurídica de esta institución puede verse en BOUIX, M. 'Tractatus de Episcopis et Synodo Diocesana', París 1859. WERNZ, F. 'Ius Decretalium', Roma 1906, t. II, n. 858. SAVAGNONE, F. 'Le origini del Sinodo Diocesano', Brugi 1910. 'Dictionaire de Droit Canonique', París 1965, VII, pp. 1134-1140 en donde encontramos una amplia descripción de muchos aspectos en la palabra 'Synode'. También en la 'Gran Enciclopedia Rialp', en las voces 'Concilio' y 'Sínodo'. Resaltamos el erudito trabajo de L. FERRER, que bajo la voz 'Sínodo' aparece en D.H.E.E., vol. IV, pp. 2.487-2.494, con un Catálogo de todos los Sínodos españoles. También en la monumetal mobra dirigida por GARCÍA-VILLOSLADA, R., 'Historia de la Iglesia en España' V volúmenes, Madrid 1979-1982, en el vol. I, pp. LVIII-LIX aparecen las colecciones y otras obras generales sobre Concilios españoles; y en volumen III, $1^{\circ}$, (ss. XV-XVI), pp. XXXV-XXXVII, relación de colecciones y otros trabajos de Concilios y Sínodos universales y españoles.

6 Es uno de los organismos más importantes que han surgido a raíz del Vaticano II. Las discusiones en el Concilio sobre el particular fueron muy vehementes y apasionantes. Puede verse en las actas del Concilio. Fue creado personalmente por Pablo VI, tras largos debates, el 15 de septiembre de 1965 con el m.p. 'Apostolica Sollicitudo', cuando comenzaba el último período conciliar. El Reglamento se promulgó el 8 de diciembre de 1966. La normativa está recogida en el Código de Derecho Canónico, cc. 342-348. Para más detalles puede consultarse cualquier edición del Codex, con comentarios.

7 Véase SANTOS DÍEZ, J.L. 'Los Concilios particulares postridentinos' y DE ECHEVERRÍA, L. 'La legislación particular canónica en la época moderna', publicados en 'El Concilio de Braga y la función de la legislación particular en la Iglesia', Salamanca, 1975. La normativa actual la encontramos en los cánones 439-446.

8 Canon 460. En siglos pasados se celebraron numerosos concilios provinciales y sínodos diocesanos especialmente a raíz del Concilio de Trento, que tanto los recomendó. Poco a poco se fue olvidando su celebración, especialmente a partir del s. XVIII. La normativa actual la recoge el Código de Derecho Canónico en los cánones 460-468. Dos hechos recientes han revalorizado la importancia de esta institución, tan decisiva para el derecho particular, que cobra así un nuevo auge. La celebración del Sínodo romano durante el Pontificado de Juan XXIII; y por otra parte las palabras del Concilio Vaticano II al recomendar: «Desea este Concilio Ecuménico que la venerable institución de los Sínodos y Concilios cobre nuevo vigor; a fin de que en las varias Iglesias, según las circunstancias de los tiempos, se provea más adecuada y eficazmente al incremento de la fe y al mantenimiento de la disciplina» (Decreto 'Christus Dominus' de 28 de octubre de 1965, nn. 28 y 36). 
Es cierto que el Codex ahora habla de sacerdotes y fieles en general, que pueden ser convocados para el Sínodo. Pero en aquella época Sínodo eran reuniones casi exclusivamente clericales, en las que el Obispo promulgaba, de la forma más solemne y como único legislador lo que consideraba más conveniente para el bien de su Diócesis. Para los Sínodos de entonces es válida la definición de Benedicto XIV en su clásica obra: «La congregación legítima reunida por el Obispo, compuesta de los presbíteros y clérigos de su Diócesis y de otros que deben acudir, en la cual se deberá tratar, deliberar y legislar sobre los asuntos pertenecientes al cuidado pastoral de la Diócesis»?

\subsection{Número de Sínodos}

Sólo tres sínodos completos se han celebrado en la Diócesis de Orihuela ${ }^{10}$. El de 1569 , siendo obispo Don Gregorio Gallo. El segundo tuvo lugar en el año 1600, bajo el pontificado de Don José Esteve Juan; y el tercero en 1663, con el obispo Don Fray Acacio March de Velasco. En una bellísima edición «apud viduam Philippi Teruel» de Murcia s.a., en $8^{\circ}$, que debe ser aproximadamente del 1670 , se recogen los tres sínodos. Los dos primeros están en lengua latina y el tercero en castellano. Sin duda el más interesante, por muchos motivos, es el segundo, celebrado por Don José Esteve, que fue un obispo de enorme talla intelectual, émulo del Patriarca valentino San Juan de Ribera ${ }^{11}$. Según refieren Ximeno V. y Rodríguez J. ${ }^{12}$, este Sínodo se editó también en Orihuela, en 1602, por Diego de la Torre; fue la primera imprenta de la provincia, y quizá la primera

9 'De Synodo Diocesana', Ferrarii, 1744, L.I, cap. I, n. 4. Se trata de una obra clásica y fundamental en su época y que describe con todo detalle la organización, funcionamiento y todo lo que ha de tenerse en cuenta para celebrar un Sínodo Diocesano.

10 Subrayamos el término completo. Todos sabemos que en el año 1979, en Alicante, se edita la obra de tres volúmenes 'Escritos Pastorales», del Obispo Dr. Don Pablo Barrachina y Estevan, que recoge la ingente labor realizada por dicho Prelado durante su largo pontificado. En el Prólogo biográfico realizado por el que fuera Vicario General Don Modesto Díez Zudaire, leemos entre otras cosas: «Terminado el Concilio Vaticano II, en el que tuvo frecuentes y certeras intervenciones, convoca y celebra el primer Sínodo Diocesano habido en España, y, como fruto del mismo, se publica el 'Estudio Sinodal: Pastoral de Conjunto'(volumen I, p. 3). Luego en el Vol. II se recogen varios escritos del Prelado sobre el Sínodo; incluso la homilía del Obispo en la solemne inauguración del Sínodo, que tuvo lugar en la Concatedral de San Nicolás de Alicante el 12 de febrero de 1967. También la homilía del acto de clausura de la primera etapa, el 26 de febrero del mismo año (pp. 77-90). Antes en el mismo volumen encontramos el anuncio del Sínodo, pp. 11-13. Sin embargo dicho Sínodo dejó de celebrar otras reuniones. No hubo acto de clausura del Sínodo ni publicación de actas y decretos del mismo. Por lo que en sentido estricto y jurídico no lo podemos calificar de Sínodo diocesano.

11 Véase una amplia biografía de este gran Obispo que fue el cuarto de la Diócesis en MARTÍNEZ VALLS, J. «Semblanza biográfica del Obispo de Orihuela Don José Esteve Juan (15511603) y sus relaciones 'ad limina'». en Anthologica Annua, Roma 1980, pp. 555-612. Hay abundante documentación hasta entonces inédita.

12 XIMENO, V. 'Escritores del Reino de Valencia, tomo I, Valencia 1747, p. 227. RODRÍGUEZ, J. 'Biblioteca Valentina', Valencia 1747, p. 211. 
obra que se imprimió. De este sínodo presentamos el estudio y las reflexiones que siguen. No hay que olvidar la enorme trascendencia que tenían en todos los ámbitos y personas de la Diócesis, dado también el apoyo regio con que contaban.

\section{EL SÍNODO DE 1600}

\subsection{Antecedentes}

El obispo Don José Esteve fue uno de esos grandes prelados propuestos por el Rey Felipe II para regir una diócesis española. Era un hombre de gran experiencia y una enorme cultura, y lleno de deseos de poner en práctica la contrarreforma auspiciada por el Concilio de Trento ${ }^{13}$.

El Concilio Provincial de Valencia, celebrado de 1565 a 1566, bajo la presidencia del célebre arzobispo Don Martín Pérez de Ayala ${ }^{14}$, marcó la normativa y disciplina a seguir en todo el reino valenciano. En esa fecha, la diócesis de Orihuela se acababa de crear y su territorio se integraba en lo religioso a la provincia eclesiástica de Valencia; el Concilio provincial fue el instrumento para la aplicación del tridentino en toda la provincia eclesiástica, que entonces, como ahora, comprendía las diócesis del reino de Valencia y las Islas Baleares.

El Sínodo diocesano de Orihuela, convocado y presidido por el Obispo Esteve, empieza, en el capítulo I, aceptando no sólo el Concilio de Trento y todas las constituciones pontificias, sino también el mencionado Concilio Provincial de Valencia y el primer Sínodo diocesano celebrado en 1569, excepto aquellos puntos que ahora se corrigen «pro temporum varietate».

No podemos entretenernos en la exposición del contenido del Concilio Provincial, que será objeto de otro trabajo que preparamos. Sólo diremos que se celebró a los dos años de clausurado el Concilio de Trento. Hubo cinco largas sesiones y trataron cuestiones relativas a la gran reforma propuesta por Trento. Así legislaron sobre la renovación en la administración de los Sacramentos, especialmente Bautismo y Matrimonio; costumbres del clero y laicos; de los

13 Tomó posesión de este Obispado el 3 de marzo de 1594, como consta en el Acta Capitular que se conserva en el Archivo de la Catedral de Orihuela (A.C.O. Arm. I, Leg. 3, rollo $9^{\circ}$, perg. 101). Haciendo la visita pastoral a Ayora cae enfermo el 14 de octubre de 1603 y muere allí el 2 de noviembre. El cadáver fue trasladado a la Catedral de Orihuela donde se celebraron las exequias y fue sepultado en la Capilla de San Esteban, hoy de Santa Bárbara. Había estudiado en la Universidad de Valencia, y fue profesor de artes y filosofía en la Universidad de Siena en Italia. Más tarde pasa a Roma, donde goza de gran estima por su erudición y elocuencia. En 1586, con treinta y cinco años, es nombrado obispo de Vieste o Vesta, en el reino de Nápoles. De aquí, pasó como Deán a la Catedral de Valencia. Poco después es nombrado obispo de Orihuela. Véase MARTíNEZ VALLS, J., 'Semblanza biográfica..., o. c.

14 Amplia biografía de este gran arzobispo, que tuvo importantes intervenciones en Trento, puede leerse en 'Diccionario de Historia Eclesiástica de España', dirigido por Aldea Vaquero, Marín Martínez y Vives Gatell, Madrid 1972, v. III, pp. 1963-1965. También GUTIÉRREZ, C. 'Españoles en Trento', Valladolid, 1951, pp. 774-793. 
neoconvertidos o moriscos; desarrollo del culto, etc. todo ello después de haber analizado diligentemente los males de esta región ${ }^{15}$. El 4 de noviembre de 1567, fue devuelto de Roma aprobado por el Papa San Pío V. El Breve de aprobación va dirigido al nuevo Arzobispo don Fernando de Loaces, oriundo de Orihuela, y que fue Inquisidor en Cataluña, obispo de Lérida, Arzobispo de Tarragona, para terminar en Valencia, donde fallece cuando estaba propuesto para el cardenalato $^{16}$. El contenido, por tanto, era de obligado cumplimiento en todo el arzobispado, y así lo recoge el Sínodo de Orihuela.

\subsection{Convocatoria y preparación del Sínodo}

La convocatoria del Sínodo lleva fecha del 31 de agosto de 1600 , estando suscrita por el Obispo Don José Esteve y por Antonio Tarí, Notario y Secretario del Sínodo. Prácticamente va dirigida a todo el clero y «a todos y cada uno de los cónsules (concejales), jurados de las ciudades pueblos y lugares de la Diócesis así como a las restantes personas seglares a los que interese».

Resalta el Prelado la importancia de este Sínodo, alaba al primer Obispo Don Gregorio Gallo que logró celebrar el primer Sínodo y corregir en parte las costumbres de la época. Una de las preocupaciones principales del Obispo es la formación del clero, convencido de que «además de los trabajos pastorales, es la cultura la que arranca la mala hierba de la impiedad y de las falsas doctrinas ${ }^{17}$. Afirma que ha tenido que dejar pasar seis años por las mismas dificultades de sus predecesores, entre las que cabe destacar los trabajos para la visita de toda la Diócesis, la consagración de la Iglesia catedral, los esfuerzos para superar las controversias para asegurar la jurisdicción sobre su Iglesia. La educación y catequesis de los moriscos, la erección de parroquias, la construcción de templos, la preparación y designación de predicadores, los problemas para erigir en Colegiata la Iglesia de San Nicolás en Alicante, etc.

El Prelado cita y emplaza en virtud de santa obediencia y bajo las penas establecidas en derecho a todos los mencionados anteriormente para que se congreguen, por sí no por procurador, en el Palacio Episcopal, el día 1 de octubre de 1600 para estudiar y «tratar de todo aquello que sirva para corregir los excesos, reformar las costumbres y tratar los asuntos que sean necesarios para el 'salus animarum', aumento del culto divino y bien y utilidad de nuestra diócesis y

15 TEJADA Y RAMIRO, J., 'Colección de Cánones y de todos los Concilios de la Iglesia española', Tomo V, Madrid 1855. El autor califica a este Concilio como «uno de los más distinguidos» celebrados en España.

16 LOACES nació en Orihuela en 1498 y murió siendo Arzobispo de Valencia el 28 de febrero de 1568. A sus expensas se construyó la Universidad de Orihuela, hoy Colegio de Santo Domingo, propiedad del Obispado. Amplia biografía puede verse en D.H.E.E., vol. II, pp. 1.133-1.134. Y LÓPEZ MAYMON, J. 'Don Fernando de Loaces', Murcia 1921.

17 Synodus Oriolana Secunda, $2^{a}$ ed. Murcia s.a., pp. 1-2. 
reforma de la Iglesia» ${ }^{18}$. Exhorta a los seglares antes mencionados a que le expongan todo aquello que beneficie al éxito del Sínodo. Sabemos que concretamente el municipio de Orihuela, recogió àlgunas peticiones que propuso al Prelado y colaboró eficazmente en la celebración del Sínodo ${ }^{19}$.

\subsection{Celebración de las reuniones}

El mismo día 1 de octubre el Obispo dirige una exhortación sobre el modo de actuar en el Sínodo, en algunos aspectos quizá con demasiada dureza. Dice que «eviten las palabras inmodestas, clamores, aplausos y gesticulaciones, pateos, tumultos, controversias, etc... y que lo que digan lo hagan con humildad y compostura» y amenaza con aplicar el rigor del derecho a los que se comportaran indignamente ${ }^{20}$.

Se hacen los nombramientos acostumbrados, entre ellos el de Prefecto del Sínodo, que debe encargarse de buscar hospedaje a los que acuden de fuera de la ciudad. El notario y el secretario coinciden en esta ocasión en una misma persona, Don Antonio Tarí. Hay que añadir los Jueces de quejas, predicadores, confesores, maestros de ceremonias, ostiarios, etc.

Desde el Palacio Episcopal se dirigen todos en procesión a la Catedral, donde se celebra la misa del Espíritu Santo, como acto de apertura de las sesiones. El Sínodo, por tanto, y según todos nuestros datos e investigaciones, se celebró en la ciudad de Orihuela. No sabemos las razones por las que un prestigioso investigador y autor moderno, parece afirmar recientemente que se tuvo que celebrar en Alicante $^{21}$.

Cuatro fueron en total las sesiones del Sínodo, que comenzaron el día 4 de octubre y terminaron ocho días después. Se formulan temas y se trabaja sobre ellos, publicándose luego los resultados en la misma Catedral. El total de decretos aprobados es de 72, abarcando muy diversas materias. Además se publican unas ordenaciones y estatutos para el clero. Termina el Sínodo con las aclamaciones...

18 Ib., pp. 7 y 8.

19 Archivo Municipal de Orihuela, 1525-1600.

20 Todo el contenido hasta aquí de este capítulo, especialmente lo que va entre comillas lo hemos resumido de 'Synodus Oriolana secunda', $2^{\mathbf{a}}$ edición, Murcia s.a., pp. 1 a 13.

21 Nos referimos al docto Profesor Dr. Don Juan Bautista Vilar, catedrático de la Universidad de Murcia, en su monumental obra «Orihuela, una ciudad valenciana en la España moderna. Historia de la Ciudad y Obispado de Orihuela», Murcia 1981. Son cuatro tomos, el último en tres volúmenes. En el tomo IV, vol. II, p. 383, leemos: «...Otra cosa fue cuando treinta años después el prelado Esteve pretendió reunir un segundo sínodo. El cabildo se opuso con todas sus fuerzas e impugnó la pretensión del ordinario en los tribunales, porque el obispo había incluido en el orden del día las cuestiones arduas. Esteve hubo de reunir la asamblea en Alicante e invocar el apoyo del brazo secular para subsanar tantos inconvenientes. Pero en Roma como en Orihuela la Iglesia comprometió su prestigio e independencia al permitir que el poder temporal se erigiera en árbitro de cuestiones estrictamente eclesiásticas». Insistimos en que no hemos encontrado nada que avale esta afirmación. Tenemos datos abundantes en pro de nuestra tesis. Y los problemas del Sínodo los tratamos más adelante en este trabajo. 


\subsection{Contenido de las sesiones $y$ decretos}

Se supone que para tomar tantas decisiones en los ocho días que duró el Sínodo, la mayoría de los temas ya estaban preparados. Esto produjo luego unas tremendas dificultades para su aplicación, que más adelante analizamos. Todo el Sínodo está redactado en latín. Algunas expresiones, muy propias de la época son difíciles de traducir. La temática general, que no podemos ahora concretar demasiado, era muy en resumen, la siguiente:

\subsubsection{Obligaciones de los clérigos en general}

Empieza recordando que todos los clérigos deben cumplir lo mandado en el Concilio de Trento, de modo que todos vistan siempre el hábito clerical y no los vestidos profanos y de color, llevando la tonsura abierta y barba pequeña, evitando todo lo que pueda ser mundano ${ }^{22}$. Se advierte que el vestido debe ser negro, dejando aparte todo lujo. Mas curiosa es la prohibición a los clérigos de «llevar armas por la noche», ya que «sus armas deben ser la oración y las lágrimas»; y si fueran sorprendidos armados por los jueces seculares «les sean quitadas», excepto aquellas que son necesarias para el uso como los cuchillos. Y exhortan a los jueces seculares a que no disimulen y permitan que vayan armados ${ }^{23}$. Se insiste en la obligación de predicar los domingos y festivos. Que no se dediquen a los negocios, ni siquiera como intermediarios; y trata de otros aspectos de la vida de piedad de los clérigos, insistiendo en la necesidad de la oración. Que no sean abogados ni procuradores. Les prohíbe asistir «a fiestas nupciales», y que si se dedicaran a encantamientos o curanderismo, serán expulsados de la Iglesia, como manda el Concilio ${ }^{24}$. Prohíbe que los clérigos se dediquen a juegos, cartas o «tablaje». Especialmente duro es el capítulo XXXVIII dedicado a los concubinarios, mandando que los hijos habidos salgan de la casa en el plazo de un mes, pasado el cual sin cumplirlo, «se les prohibirá entrar en la Iglesia; y si pasara otro mes serán suspendidos de sus oficios y beneficios, amenazando con «mayores penas» a los contumaces. Exige que las mujeres que tomen a su servicio tengan al menos cuarenta años. Hay que reconocer que en aquella época, con

22 Sesión XIV, cap. 5 y cap. 36.

23 Ib., cap. XXXIV. Se recuerda también lo ordenado sobre esto por el Concilio provincial valentino, sesión III, cap. 4. Sobre la vida y costumbres de la época y la necesaria reforma de en general, y del clero en particular, tanto regular como secular, asi como de los monasterios femeninos, puede leerse la abundante información aportada por AZCONA T., GARCÍA ORO J. y GONZÁLEZ NOVALÍN J.L., en sus sendos y documentados trabajos en la ya mencionada obra dirigida por GARCÍA VILLOSLADA R., Vol. III-1², Madrid 1980, pp. 115-384.

24 Cap. LXV. Es curioso constatar que este capítulo empieza reconociendo que es costumbre en esta Diócesis, como en muchas regiones de España, no buscar remedio en las artes médicas, sino en «curanderos» y otras supercherías y supersticiones. 
tanto clérigo que abrazaba este estado como un «modus vivendi», sin la vocación y preparación adecuadas, había algunos que ciertamente no se comportaban como exigía su condición, con el correspondiente escándalo. El Obispo puso mucho empeño en corregir ciertas conductas y abusos y corruptelas.

\subsubsection{De las personas eclesiásticas en particular}

Canónigos. Párrocos. Rectores de iglesias. Vicarios. Vicarios foráneos o rurales. Coadjutores. Visitadores. Se detallan las obligaciones propias de cada uno. Entra en minuciosos y numerosos detalles, que nos descubren las malas costumbres y corruptelas existentes en la época y el afán del Obispo por corregirlas. Pide compostura y buenas formas en el coro. Que no celebren reuniones durante los oficios o celebración de la Misa capitular. Es curioso que se mande que los subdiáconos y diáconos reciban la eucaristía dos veces al mes, además de las fiestas solemnes, y que los presbíteros deberán celebrar la santa Misa al menos los domingos ${ }^{25}$.

\subsubsection{De los laicos en particular}

Maestros. Jueces y Magistrados. Pobres. Padres y Cabezas de familia. Herederos y ejecutores testamentarios. Omitimos ahora todo lo referente a los cristianos nuevos o moriscos; se trató con amplitud en este Sínodo y en otras disposiciones ${ }^{26}$.

Hemos de reconocer que algunas normas ahora nos hacen sonreir. Otras, por el contrario, nos ponen de manifiesto una serie de abusos y costumbres que hoy ya no podríamos comprender, y que felizmente se han superado y desterrado. Por citar un ejemplo sencillo, comer o cantar estrofas profanas y vulgares en la Iglesia. De todo este apartado sobre los laicos sólo queremos resaltar el recordatorio que se hace a los Jueces y magistrados para que no permitan que los clérigos vayan armados. Les pide por el bien del Estado, que supriman los escándalos de las vías públicas, y eviten que las meretrices vivan cerca de las iglesias y escuelas públicas $^{27}$. También les exhorta a que vigilen la ciudad por la noche y eviten que en las calles, puertas y ventanas se pinten cosas obscenas, y que no permitan que

25 Ib., cap. LIV. Es tan extenso todo lo relativo a los clérigos que merece un trabajo concreto. Por obvias razones de brevedad, no podemos ahora exponer todo lo mandado.

26 Sobre los moriscos de esta época véase nuestro trabajo 'Los moriscos en la Diócesis de Orihuela a finales del s. XVI y legislación particular sobre los mismos', en Anales de la Universidad de Alicante, Facultad de Derecho, n. 1, Alicante 1982, pp. 243-272. Seguimos profundizando en esta línea de investigación y hemos encontrado nuevos datos, que serán objeto de una próxima publicación.

27 Ib., cap. XL. 
los hombres vaguen tumultuosamente por la noche, ya que se producen graves escándalos, además de la pública ignominia ${ }^{28}$.

Respecto a los pobres se pide a los pudientes que, a ejemplo de la ciudad de Valencia, los sábados de todo el año les ayuden por familias y casas. Y pide que en todas las parroquias se designen dos varones probos y diligentes al principio de cada año, que lleven un libro donde anoten lo recibido y lo dado ${ }^{29}$.

Sobre los padres y cabezas de familia. Varios capítulos dedica el Sínodo a recordar las obligaciones paternas, descendiendo a detalles concretos. Por citar sólo algunos, insiste que deben instruir a sus hijos y familia en el culto a Dios y en el ejercicio de la piedad y éxhorta a todos, a no ser que quieran «in die Domini» tener un durísimo juicio, a que sean solícitos con su familia, dando buen ejemplo y siendo maestros de vida santa. Deben procurar que todos, hijos y sirvientes, aprendan los rudimentos de la fe cristiana y que confiesen y comulguen al menos una vez al año, y asistan a Misa los domingos. Que lean libros buenos y vigilen la marcha de su casa. Manda que prohíban a sus hijos y esposas la costumbre de acudir por la tarde e incluso entrada la noche, tapada la cara y vestidos de «peplo» a casas privadas, en donde se organizan bailes descarados y se cantan canciones. A esta costumbre la califica de «peste» ${ }^{30}$. Finalmente en el cap. LXIII les exhorta a que vigilen la educación de los hijos, especialmente la de los de más tierna edad, y que no permitan que reciten versos libidinosos y los aparten de todos los vicios.

\subsubsection{De los Sacramentos}

No fue nota distintiva de este Sínodo hacer un estudio en profundidad sobre los Sacramentos, dando por válido todo lo dicho en el Concilio de Trento y en el Concilio Provincial de Valencia y lo establecido en el primer Sínodo diocesano. Da la impresión de que al Obispo lo que más le preocupaba era la reforma de las costumbres y corregir ciertos abusos. Se asume el ritual Valentino, proscribiendo el Cartaginense. No se trata de todos los sacramentos, sino sólo aquellos que por su importancia y repercusión social adquieren un mayor relieve a los ojos de los fieles. Así se dan disposiciones sobre el Bautismo ${ }^{31}$.

28 Ib., cap. LVIII. Hace referencia también a la costumbre de cantar letanías, añadiendo peticiones o frases obscenas.

29 Ib., cap. XXVI. A1 hablar de los párrocos les exhorta al cuidado preferente de los necesitados. Y este precepto aparece en varios capítulos del Sínodo. Entonces, como ahora, los pobres tenían la costumbre de situarse a la entrada de los templos. Se habla también de los llamados «pobres vergonzantes», cuya condición les impedía pedir a la entrada de las iglesias, recomendando su cuidado y ayuda.

30 Ib., cap. LXI.

31 Se exige que las pilas bautismales sean de piedra, dando un plazo de seis meses para cambiar todas las que fuera necesario. Que se guarde la debida compostura durante la ceremonia y que se escoja bien y previamente al padrino, que ha de ser persona conocida de los padres. Al parecer estaba bastante extendida la costumbre de algunos de «coger al primero que pasara por la calle». Cap. V. 
a) En cuanto a la Penitencia se prohíbe oír confesiones en casas particulares, a no ser que fueran llamados por el médico en caso de enfermedad ${ }^{32}$. Se dice que se demore la absolución a los usureros, meretrices, concubinarios, jugadores y a los que participan en juegos prohibidos y/o cometen pecados públicos. Tampoco podrán ser absueltos los encargados testamentarios si en el plazo de un año no se han cumplido las voluntades del difunto ${ }^{33}$. Más espectacular era la larga lista de pecados reservados al Obispo, con el fin de corregir los más graves delitos ${ }^{34}$.

b) Sobre la Eucaristía se contempla especialmente la administración a los enfermos, que será diurna; se prohíbe que se lleve de noche, salvo por la gravedad del enfermo, certificada por el médico. Se recuerda que es comida y viático para la vida eterna, y no para que lo veneren «o lo tengan en la boca» ${ }^{35}$. Da normas sobre los estipendios de las misas, prohibiendo bajo excomunión recibir varios estipendios por una Misa, y ordena que se celebren en todas las Iglesias, prohibiéndolo en las Ermitas u oratorios privados. La primera se celebrará al despuntar el alba, y la última no después de las once. En caso de peste se celebrará todos los martes la misa de San Roque en todas las Iglesias ${ }^{36}$. Se manda que en la Iglesia los hombres estén separados de las mujeres; y que cuando estas comulguen lo hagan en el último peldaño y no dentro del altar, «con la cabeza cubierta, honestamente, no adornadas ni pintadas $»^{37}$. No es de extrañar que nada se diga sobre la comunión de los niños, que entonces comenzaba mucho más tarde, bien entrada la pubertad ${ }^{38}$.

c) Muy importante es lo relativo al Matrimonio. No olvidemos que fue el Concilio de Trento el que estableció por primera vez en la historia de esta institución, la obligación «ad validitatem» de la forma jurídica. El 11 de noviem-

32 Ib., cap. XIX.

33 Ib., cap. XXX.

34 Eran los siguientes: herejía, sacrilegio, homicidio voluntario, provocado o por traición o inducción; heridas nocturnas por venganza; incendio nocturno de mieses; robo de aguas de riego; incesto; pegar a los padres; procurar el aborto; el matrimonio clandestino; perjurio en juicio; sodomía, bestialidad; promoción a órdenes sagradas por medio de testigos falsos o falso título; calumnias graves contra sacerdotes para que sean removidos de su cargo con tumulto del pueblo; conspiración contra los sacerdotes; cualquier provocación en confesión. (Cap. LXX).

35 Ib., cap. XXII. Añade normas sobre el número de acompañantes.

36 Ib., cap. XVII.

37 Ib., cap. XIX.

38 La razón es obvia. En aquella época, y según mandó el Concilio provincial de Valencia de 1565 , la edad prudente para recibir la comunión era entre los 12 y 14 años. Incluso con el pretexto de una mejor preparación, en muchos sitios en el s. XVII la primera comunión se retrasaba hasta los 16 años. No olvidemos que la primera comunión al alcanzar el uso de razón es costumbre establecida sobre todo en tiempos de San Pío X. Además en aquella época se comulgaba pocas veces, estando mandado al menos una vez al año por Pascua. La comunión tan frecuente como ahora es muy reciente, especialmente desde después del Concilio Vaticano II. Véase JUNG, N. en 'Dictionaire de Droit Canonique', Paris 1942, tomo III, col. 1098-1180 en la voz 'Communion'. TESTORE C. 'Comunione Eucaristica', en Enciclopedia Cattolica, vol. IV, Firenze 1950, col. 125-142. 
bre de 1563 se aprueba el famoso decreto «Tametsi» ${ }^{39}$, en el que se establece, por vez primera en la historia, que el matrimonio para que sea válido, hay que celebrarlo ante el párroco y dos o tres testigos. Hasta entonces no se exigía una determinada forma para la validez del matrimonio, bastando el simple consentimiento mutuo, aun en privado y sin testigos. Eran los llamados matrimonios clandestinos. En España y sus dominios el decreto «Tametsi» se convierte en ley del reino por la Real Cédula de Felipe II del 12 de julio de 1564, por la que se aceptan todos los decretos de Trento en general, y en particular el relativo al matrimonio ${ }^{40}$. Se intenta así terminar con tanta situación irregular y/o de bigamia. Pero la reforma tridentina costó mucho y tardó tiempo para introducirse y arraigar en las costumbres de muchas gentes y lugares.

Ya en el primer sínodo se puso de manifiesto la preocupación del obispo y sinodales por la multitud de matrimonios clandestinos, estableciéndose unas normas. Este segundo Sínodo intenta completar la anterior disciplina. Quiere evitar los abusos de las uniones sin haber recibido el rito religioso del sacramento. Afirma que muchos tienen relaciones carnales antes de que se hagan las amonestaciones o contraigan matrimonio ante el párroco y los testigos. Frecuentemente ocurre que el futuro marido, una vez que ha cohabitado con la mujer, la abandona porque el amor se torna aversión y prefiere deshacerse de ella antes de casarse. Muchos también consuman el matrimonio en los grados prohibidos, antes de obtener la dispensa.

El Sínodo prohíbe, bajo pena de excomunión, que los padres o tutores entreguen a la futura esposa al marido, o que conviva con ella en la misma casa. Se aplicarán graves penas a aquellos que tuvieran relaciones carnales antes del rito sacramental ${ }^{41}$.

39 Esta temática puede verse en cualquiera de los numerosos manuales o diccionarios especializados. Las razones fueron principalmente acabar con la plaga de los llamados matrimonios clandestinos, que se celebraban privadamente por el mutuo consentimiento. Luego, algunos, al no existir constancia y ser privados, volvían a contraer matrimonio con otras personas; por seguridad jurídica y para acabar con tantas situaciones de bigamia, al menos de facto, se dictó este Decreto, en el que fue tan decisiva la intervención de los obispos españoles. En la práctica la necesidad de una forma jurídica para contraer matrimonio fue pasando a todos los estados, incluso a los no católicos. Los problemas que aun planteaba dicho decreto tridentino fueron zanjados definitivamente por San Pío X con el Decreto «Ne temere» del 2 de agosto de 1907, y que recogió el Codex de 1917 y el de 1983. Existe abundantísima bibliografía sobre el particular, y es una de las instituciones más estudiadas. Después del Vaticano II, las controversias que suscita esta problemática ha vuelto a alcanzar cotas muy altas.

40 Un documentado estudio sobre la participación de España en el Concilio de Trento, la labor de Carlos V y de Felipe II, y en particular sobre la aceptación por Felipe II de todos los decretos conciliares, puede verse en LLORCA VIVES B. 'Participación de España en el Concilio de Trento', en GARCÍA-VILLOSLADA R., o.c., vol. III- $1^{\circ}$, pp. 385-513. Sostiene este prestigioso autor que la aceptación en España del Concilio de Trento fue «rápida, general y absoluta. Es decir, en ella no se puso ninguna limitación, ni siquiera la general, que algunos suponen, de 'salvos los derechos reales'», Ib. pp. 495 y ss.

41 Ib., cap. LVI. Naturalmente cuando los hechos eran públicos y notorios. Todo este problema nos ayuda a reflexionar sobre ciertas situaciones actuales, uniones de hecho, etc., que han merecido la atención de los especialistas, y han sido objeto de reuniones y congresos y se han escrito numerosos trabajos. 
Se ordena también que no organicen tumultos ni «cencerradas» con motivo de segundas nupcias, y llega a excomulgar a los promotores de estos alborotos ${ }^{42}$.

\subsubsection{Otras disposiciones}

Resumimos las más importantes. Para fomentar la devoción a la Virgen se manda guardar las vigilias de sus fiestas. Se prohíbe que se vistan las imágenes de los Santos de forma exagerada y mundana. Se prohíbe que las imágenes de la Virgen María sean vestidas como las demás mujeres. Están prohibidas también las imágenes de Cristo, la Virgen o de los Santos, que se muevan o hagan gestos, que en lengua vulgar llamamos «títeres»; no se las tolera ni en las Iglesias ni fuera, pues incitan más a la irrisión que a la devoción ${ }^{43}$. Se insiste en que no se pueden hacer representaciones de comedias y mimos en las Iglesias, según mandó Inocencio III. Se prohíben también los cantos vulgares ${ }^{44}$, ridículos, 0 «en lenguas etiópicas» (sic) o extrañas. Los cantos deben ser modestos y graves, y que fomenten la devoción y no las risas y la distracción ${ }^{45}$.

Se recuerda la obligación de pagar los diezmos de los frutos de la tierra ${ }^{46}$. Se prohíbe que los cofrades se gasten el dinero de la cofradía, en las vigilias de sus patronos, en alborotos, fuegos, toros, etc., o que de buena mañana recorran las calles tumultuosamente ${ }^{47}$.

Otro mandato curioso es la prohibición de acudir a los curanderos, so pretexto de religión, costumbre extendida en casi toda España. Se manda que se vaya a los médicos, y que no hagan encantamientos ni oraciones vulgarmente llamados de Gelmatores. Finalmente se señalan los días festivos en la Diócesis, además de los domingos, y las especiales de Orihuela, Alicante y otros lugares ${ }^{48}$.

Resulta imposible, en este forzosamente breve trabajo, recoger todos los detalles y disposiciones de este segundo Sínodo. Consideramos suficiente lo expuesto para darnos una cabal idea de los muchos problemas abordados, y el gran empeño en reformar y corregir tantas cosas, de acuerdo con lo mandado en Trento.

42 Ib., cap. LVIII.

43 Ib., cap. XIV.

44 Creemos que también habría algún problema con el famoso Misteri de Elche. Aunque lo que prohíbe el Sínodo son las representaciones mundanas. Dada la gran religiosidad y seriedad del Misterio, logró superar las prohibiciones de Trento, como es bien sabido.

45 Ib., cap. XXIV, y cita la Bula «Cum decorem» de Inocencio III.

$46 \mathrm{Ib}$., cap. XLIX. Fueron numerosos los pleitos de los obispos con los señores temporales, pues en muchos lugares cobraban ellos los décimos, sobre todo a los moriscos, suponiéndoles grandes rentas. Luego mal pagaban al sacerdote o párroco, llamado por esto «mercenario».

47 Ib., cap. LII.

48 Ib., cap. LXV y LXIX. 


\section{DIFICULTADES PARA LA APLICACIÓN Y EJECUCIÓN DEL SÍNODO}

El Obispo encontró grandes problemas y enormes dificultades para la ejecución de los decretos de este Sínodo. Realmente algunos mandatos del Sínodo resultaban muy duros para unas personas que durante tanto tiempo estaban acostumbrados a un género de vida que, en ocasiones, desdecía de su condición de cristianos y/o, sobre todo, de clérigos. La oposición más fuerte procedía precisamente del mismo clero, y más en concreto del Cabildo Catedral. En efecto, unos días después de clausurado el Sínodo, concretamente el día 17 de octubre, el Obispo se ve precisado a escribir una carta al Romano Pontífice Clemente VIII. Le da cuenta de la celebración del Sínodo en la Catedral durante ocho días y de las grandes y necesarias reformas que pretendía introducir para corregir los abusos y exterminar las depravadas costumbres y vicios extendidos en la Diócesis. Le anuncia que le envía un ejemplar de los Estatutos del Sínodo «fideliter transcriptum ${ }^{49}$, para que vistos y aprobados por la Sede Apostólica, puedan ser ejecutados más fácilmente; añade que lo hace así porque el Cabildo ha apelado con el pretexto de que el Sínodo necesitaba el consentimiento previo y la aprobación de los estatutos por el Cabildo ${ }^{50}$.

Sin duda esto último era un pretexto, y la razón verdadera era que no estaban dispuestos a renunciar a ciertos privilegios y sobre todo a cambiar sus costumbres y modos de vida. En efecto el Obispo había recibido una carta del cardenal Mattheo de fecha 27 de mayo de 1599, en la que le decía que según la Congregación el Obispo «puede convocar Sínodo» sin el consentimiento del Cabildo y que puede promulgar las constituciones sin el consentimiento y aprobación del Clero. Debe pedir el consejo del Cabildo, pero no está obligado a seguirlo, excepto en lo establecido expresamente por el derecho ${ }^{51}$. Nos imaginamos cómo estarían los

49 El Papa lo envió a la Congregación de Cardenales para interpretar el Concilio. Es un magnífico ejemplar, cuidadosamente escrito, que hemos encontrado en la misma Sagrada Congregación del Concilio, hoy del Clero, y que conservamos fotografiado. Tiene la particularidad de que contiene con letra distinta los puntos sobre los que apeló el Cabildo. A.S.C.C. Oriolen.

50 Esta carta la encontramos en el Archivo Secreto Vaticano. S.C. Concilii. Relationes ad limina. Oriolensis A. La tenemos transcrita y publicada en 'Anthologica Annua', 1980, o.c., pp. 593594. También en «Las primeras relaciones y visitas 'ad limina' de la Diócesis de Orihuela», en 'Studia in Honorem Vicente Martínez Morellá', Valencia 1985, pp. 245-280. Entre otras cosas escribe el Obispo: «...praepositus et Capitulum Oriolen ab his dumtaxat statutis atque decretis in quibus chori disciplina, et silentium, psallendi modus, modestia in processionibus, et supplicationibus servanda, tempus cogendi capitulum praescribitur, quae in eorum praecipue reformationem et disciplinam diriguntur, appellandum esse censuerunt, eo praetextu quo eiusmodi statuta eorum consensum et approbatione fieri, promulgarique deberent».

51 Todo esto indica que ya antes se había planteado el problema y el Obispo quiso atar bien todos los cabos. Se publica íntegra en la misma edición tan citada 'Synodus Diocesana secunda', pp. 315-316. ¿Es que acaso el Obispo no la había hecho pública antes de comenzar el Sínodo? Es muy extraño. Pero no tenemos elementos de juicio suficientes para opinar en uno u otro sentido. Resulta muy grave que, una vez conocida por el cabildo, este persistiera en su actitud. 
ánimos para que el Obispo, de carácter enérgico y gran personalidad, no se atreviera a publicarlo enseguida, a pesar de la carta antes mencionada, y prefiere contar de nuevo con la autorización expresa de la Santa Sede, acudiendo al organismo que consideraba competente ${ }^{52}$.

La Congregación romana respondió pronto al Obispo, de forma muy diplomática, en la que por una parte le dice que no era de su competencia examinar los Sínodos, sino los Concilios provinciales ${ }^{53}$; pero, dada la gran opinión que tiene del Obispo, escogen algunos estatutos que presentaron a los padres Cardenales y recogieron su parecer. Con lo cual no se apartan de la praxis de la Congregación y dan satisfacción en parte a lo pedido por el Obispo.

Lo cierto es que el Obispo no se atreve a ejecutar todas las disposiciones del Sínodo. Y en la visita «ad limina» del año siguiente ${ }^{54}$, envía otra carta fechada el 1 de octubre de 1601, en la que insiste al Papa de su intento de reformar las costumbres y las dificultades encontradas. Del Sínodo afirma que ha sido aceptado por todos, «solo Capitulo reclamante ${ }^{55}$.

52 Terminado el Concilio de Trento, Pío IV instituyó un órgano compuesto por ocho cardenales para vigilar la observancia del mismo, teniendo al principio funciones sólo ejecutivas. Más tarde el número de Cardenales fue elevado a doce y bajo el Pontificado de Pío V se le concede la facultad de poder interpretar los decretos conciliares, resolviendo «authentice» las dudas que no fueran graves. Era también misión de dicha Congregación vigilar la regularidad de los Concilios provinciales y Sínodos diocesanos; examinar y aprobar las actas de los Concilios provinciales, procurar «in universo orbe christiano» la reforma del clero y del pueblo, etc. etc. Este organismo se denominó 'Sacra Congregatio Cardinalium Concilii Tridentini interpretum'. La competencia y autoridad de esta Congregación era muy grande, llegando incluso a resolver causas judiciales, conceder gracias e indultos, etc. Estas era su competencia casi hasta la reforma de Pío X, con la constitución del 11 de febrero de 1911, en que se llama Congregación del Concilio y limitó su competencia al crear la Congregación de Sacramentos, dejándole sólo la disciplina del clero y del pueblo. Es bien sabido que en la actualidad esta Congregación ha pasado a llamarse del Clero. Amplio estudio. Véase ROMITA, F. «Le origini della S.C. del Concilio» en 'La Sacra Congregazione del Concilio. Quarto Centenario dalla Fondazione (1564-1964). Studi e ricerche'. Città del Vaticano 1964, pp. 13-50. Y en general toda la obra, en donde se recoge también abundante bibliografía. Recientemente ha publicado un estupendo trabajo sobre la S. C. del Concilio CARCEL ORTI, Mercedes, en su obra 'Relaciones sobre el Estado de las Diócesis valencianas', Valencia 1989, I, pp. 109-206. Obra que merece todos los elogios por el enorme caudal de documentos y datos que, en su gran mayoría, ahora se publican por primera vez.

53 Según consta en el libro de registro de dicha Congregación, contestaron el 27 de diciembre de 1600, y entre otras cosas dicen: «...non consuevit Sacra Congregatio Card. Conc. Trid. interpretum dioecesanos synodos recognoscere vel emendare, pro Synodis tantum provinciliabus id operis atque laboris suscepit...». A.S.C.C. Libri litterar. Conc. VIII, 1598-1606, fols. 67v-68r.

54 Realizada por Procurador, como era costumbre general en la época. En esta ocasión fue su mismo hermano Vicente Esteve.

55 En esta carta, además de otros asuntos, el Obispo repite las razones indicadas en la carta del 17 de octubre de 1600 por las que se oponía el Cabildo; pero añade otras mucho más graves. Llega a decir, que el Cabildo apela porque «...caín multa ad pietatem instituta, et maxime circa sacramentorum edidisset, et pessimos sacerdotes, qui in provocandis ad libidinem feminis inter confitendum studebant, censura Eclesiastica et poenis gravissimis compresisset; atque eos qui liberos spureos domi educabant, ad eorum expulsiones coëgisset...», termina suplicando que mande al Cardenal Mattheo que estudie el caso y que responda cuanto antes. A.S.V., Congr. Concilii. Relationes ad limina. Oriolensis, fol. 490. La tenemos publicada íntegra en 'Anthologica Annua', Roma 1980, o.c., pp. 608-612. 
No sabemos si Roma llegó a contestar. Lo que sí sabemos es que el Obispo, en sus visitas pastorales a las parroquias, empezó a aplicar, en la medida de lo posible, las disposiciones sinodales. Y que el año 1602 fue impreso en Orihuela, como hemos escrito al principio de este trabajo.

Después de la muerte del Obispo en Ayora el 2 de noviembre de 1603, los ánimos todavía estaban tan exaltados, que el mismo Rey Felipe III escribió una carta al Cabildo unos días antes de la toma de posesión del nuevo Obispo; en ella intenta apaciguar las personas y relaciones y restablecer la paz, preparando así los caminos para la llegada del sucesor.

De todas formas, todavía quince años después, concretamente el 22 de junio de 1615, en la visita «ad limina» que realiza a Roma el entonces Obispo Don Fray Andrés Balaguer Salvador ${ }^{56}$, por Procurador, se excusa ante el Papa de no haber podido celebrar Sínodo «porque algunos mandatos de nuestro predecesor, celebrado en 1600, todavía no han podido ser ejecutados»; aunque es cierto que también apunta otros motivos, como los problemas suscitados por la expulsión de los moriscos ${ }^{57}$. Pero con la palabra «algunos» está indicando que la mayoría, o al menos gran parte de los mandatos, ya se habían ejecutado.

Quizá el mayor error del Obispo fue querer corregir, tan rápidamente, ciertos abusos, corruptelas y vicios, que ya estaban muy arraigados y casi tenían naturaleza de «costumbres», como si de cosa sencilla se tratara. Otras cosas ciertamente constituían abusos y vicios execrables que no había más remedio que intentar cortar de raíz. De todas formas es bien sabido que incluso lo que sea detestable, si lleva ya tiempo y no es un caso aislado, hay que corregirlo con moderación y mucha prudencia.

\section{IMPORTANCIA Y PROYECCIÓN UNIVERSAL DEL SÍNODO DE 1600}

La trascendencia del Sínodo fue enorme, no sólo a nivel diocesano, sino también a nivel nacional e incluso mundial.

Es cierto que se trataba de un Sínodo demasiado ambicioso y exigente, y de aquí sus dificultades para la celebración y grandes problemas para su aplicación. Con toda firmeza quiso aplicar las reformas auspiciadas por el Concilio de Trento, y recordadas por el Concilio provincial valentino, especialmente entre un abun-

56 Gobernó la Diócesis desde el 19 de enero de 1905 hasta su fallecimiento el 11 de abril de 1926.

57 A.S.V., Congr. Concilii. Relationes ad limina. Oriolen. La teníamos transcrita. Después ha sido publicada en la monumental obra de CARCEL ORTI, Milagros, 'Relaciones sobre el estado de las diócesis valencianas', Valencia 1989, vol. I, Orihuela, pp. 357-363. Son tres tomos editados por la Consellería de Cultura, Educació i Ciencia de la Consellería Valencia. Obra que consideramos fundamental para el estudio de tantos aspectos de la Comunidad Valenciana. Se recogen todas las 'Relaciones' de las visitas «ad limina» realizadas por el Arzobispo de Valencia y los Obispos de Orihuela y de Segorbe, desde finales del s. XVI. 
dante Clero $^{58}$, que no brillaba, en gran parte, por su ciencia y sobre todo por su entrega y dedicación al servicio pastoral. Las costumbres de algunos no eran precisamente ejemplares. Lo mismo hemos de decir de muchos cristianos.

El investigador Juan Regla hace una descripción que consideramos objetiva de la situación de la época. Afirma que los clérigos constituyeron la aristocracia de la cultura del país. Pero al lado de una minoría selecta existía una masa ruda, con escasa preparación, satirizados por la literatura de la época. Cisneros no logró desarraigar las graves faltas en que incurrían los eclesiásticos. El mal era común en toda Europa, y en contra de ello reaccionaron las reformas disciplinarias de Trento. «Abundaban los clérigos amancebados y los frailes alegres y moceros en los que de un modo raro y sorprendente se mezclaban la lubricidad con la religión... Sin embargo, en la segunda mitad del s. XVI se impuso el celo religioso de Felipe II y de la inmensa mayoría de jerarquías eclesiásticas» ${ }^{59}$.

También el conocido investigador Antonio Domínguez Ortiz ha publicado un documentado trabajo en el que habla de la Iglesia y la sociedad española en aquella época. Cuenta que las motivaciones para acceder a la clerecía o vida religiosa eran muy variadas. Sin duda influyó el aspecto económico, el sistema beneficial, «pues había en la Iglesia española cargos tan excelsos que no eran indignos de hijos de reyes». Pero también existían otras razones de tipo social: segundones que así accedían a una capellanía familiar; en casos, tener un «modus vivendi», ser bien considerados, etc. Mujeres con borrascas sentimentales o que habían perdido el favor de grandes nobles, y buscaban refugio en un convento. Esto explica en parte la lamentable situación de bastantes miembros de órdenes religiosas - masculinas y femeninas - así como de clero secular. El interés y empeño de nuestros reyes y obispos por la reforma de costumbres fue extraordinaria ${ }^{60}$. Otros autores, en la misma Obra, hablan de las reformas emprendidas desde Cisneros.

Creemos que en parte esta situación era la existente en la Diócesis de Orihuela en tiempos del Obispo Esteve. Su interés y su celo por corregir las costumbres,

58 Algún autor ha escrito que en la España de los Austrias el 1'2 \% de la población total pertenecía al estamento clerical o religioso. Así lo dice DOMÍNGUEZ ORTIZ A. «aspectos sociales de la vida eclesiástica en los s. XVII y XVIII: la Iglesia y la sociedad española en el s. XVII y número y procedencia del Clero» en 'Historia de la Iglesia en España', dirigida por VILLOSLADA R.G., Madrid 1979, Vol. IV, pp. 5-45. Sólo en la Catedral de Orihuela, según datos de las visitas «ad limina» había cuarenta clérigos y algunos beneficios de capillas privadas que no tenían la obligación de residencia. En total solo en la ciudad de Orihuela, según nuestros datos, había más de doscientos clérigos y religiosos, en una población de unas 3.000 casas, o sea cerca de 15.000 habitantes. En Alicante había un total de 92 clérigos y más de 70 religiosos para una población de unas 2.000 casas, es decir quizá menos de 10.000 habitantes, El modo y razones por las que muchos accedían a la clerecía explica que algunos de ellos no fueran precisamente ejemplares en sus conductas.

59 REGLA, J. «La época de los tres primeros Austrias», en 'Historia de España y América, social y económica' dirigida por VICENS VIVES, Barcelona 1977, vol. III, p. 66.

60 DOMÍNGUEZ ORTIZ A., 'Aspectos sociales de la vida eclesiástica en los siglos XVII y XVIII', en la obra dirigida por GARCIA-VILLOSLADA R., o.c., vol. IV, pp. 5-71. Naturalmente analiza la situación que ya traía su origen de siglos anteriores. 
sobre todo del Clero, le proporcionaron no pocos disgustos y problemas. Había, en efecto, muchas cosas que corregir y el Obispo Esteve había decido hacer todo lo posible por cortar los males y abusos.

Sin duda la reforma de este Sínodo diocesano poco a poco fue calando en las mentes de casi todos; olvidando las rencillas e incluso odios personales, fueron reconociendo los aspectos positivos y sirvió para corregir ciertos abusos y algunas situaciones escandalosas; y en general supuso una auténtica renovación y mejora de las costumbres. Algunas de las cosas expuestas aquí, hoy están ya totalmente olvidadas, e incluso causa estupor pensar que pudieran haber existido.

De hecho, en el tercer Sínodo que se celebró en el mes de abril de 1663, siendo Obispo de la Diócesis Fray Acacio March de Velasco ${ }^{61}$, ya no se tratan muchos aspectos, quizás los más graves, que fueron analizados en el Sínodo de Esteve y con tanta firmeza se intentaron corregir. Esto es señal inequívoca de que los males más graves ya se habían superado, o, al menos, eran tan excepcionales que ya no merecían un tratamiento específico en Sínodo.

Con razón todos los autores que han escrito sobre Don José Esteve Juan resaltan en sus obras la realización de este importante Sínodo ${ }^{62}$.

En cuanto a su proyección nacional y mundial hemos de señalar que en la monumental obra del erudito cardenal José Sáenz de Aguirre, publicada en 1693, se recogen todos los Concilios provinciales de la época; pero entre los numerosos Sínodos diocesanos celebrados en España y el Nuevo Mundo, solamente coloca en su obra el Sínodo diocesano de 1600 de Don José Esteve; y por si fuera poco añade el elogio de Don Nicolás Antonio, con la relación de algunas de sus obras $^{63}$. Creemos que esto es sumamente significativo de la importancia que el Cardenal atribuyó a este Sínodo; sin duda se hizo famoso, además de por su contenido, porque trascendió en Roma, y de aquí a otras partes, la gran polémica suscitada, con motivo de su celebración y posterior aplicación, entre el Obispo y el Cabildo. No olvidemos que el Obispo Esteve era bien conocido en Roma y gozaba de gran prestigio ${ }^{64}$; no es de extrañar que, aunque ya hacía años que había

61 Biografía de este Obispo puede verse en VIDAL TUR, G. 'Un Obispado español. El de Orihuela-Alicante'. 1962, vol. I, pp. 256-271.

62 Véase, por ejemplo, XIMENO, RODRÍGUEZ u ORTI FIGUEROLA, por citar los más antiguos. O VIDAL TUR, o.c., entre los modernos, y MARTÍNEZ VALLS, J. «Semblanza biográfica...», o.c.,

63 Nos referimos a la 'Collectio maxima Conciliorum omnium Hispaniae et Novi Orbis', Roma 1693. Nuestro Sínodo con el elogio de Antonio lo encontramos en el tomo. IV, pp. 713 y ss.

64 Había residido en Italia, como ya hemos dicho, siendo profesor en la Universidad de Siena. Luego se traslada a Roma, donde, según Ximeno, destacó por su erudición y buen decir. Estando en Italia publica varias obras teológico-jurídicas. Señalamos, entre otras, «De potestate coactiva, quam Romanus Pontifex exercet in negoria secularia. Liber primus.» Hay dos ediciones, Roma 1586 y 1588. Dedicado al Papa Sixto V. Como hecho que denota su enorme erudición hemos de destacar que, a su muerte, y en cumplimiento del espolio que realiza el Nuncio según norma de la época, se embarcan an Alicante para Roma « 22 cajas cubiertas que contienen 1595 tomos que constituian la biblioteca del Obispo de Orihuela». Cantidad ciertamente muy importante en aquellos tiempos. 
fallecido, continuara vivo su recuerdo y el Cardenal sintiera una gran admiración por el docto Obispo Esteve, que supo luchar y plasinar en ese Sínodo el espíritu de la reforma de Trento.

Finalmente queremos añadir que los problemas suscitados y planteados con motivo de este Sínodo, contribuyeron en parte al derecho universal de las Iglesia. En efecto el Papa Benedicto XIV, en su fundamental obra «De Synodo Dioecesana», editada en 1744, cita por dos veces el Sínodo de Esteve, para documentar algunas de las disposiciones expuestas en dicha obra y que durante tantos años han servido de guía imprescindible para numerosos sínodos diocesanos celebrados en todo el mun$\mathrm{do}^{65}$. No hay ninguna otra cita en dicha obra de los restantes sínodos orcelitanos.

\section{EPÍLOGO}

Muy en resumen hemos esbozado lo que consideramos más importante del Sínodo de 1.600. A pesar de los grandes problemas suscitados, el balance del mismo lo consideramos altamente positivo y en muchos y variados aspectos. Por otra parte el inteligente lector habrá observado que los sínodos diocesanos son una inmejorable fuente para investigar $\mathrm{v}$ descubrir no sólo aspectos religiosos y jurídicos de una determinada época. En general son de un enorme valor documental de todo tipo, también antropológico y social. A través de las disposiciones sinodales podemos dibujar el modo de ser y vivir de nuestros antepasados, su religiosidad y sus costumbres y estilos de vida, con sus grandes virtudes y sus vicios, con sus luces y sus sombras. Los esfuerzos de aquellos Obispos por conservar, difundir y afianzar la fe cristiana y corregir ciertos abusos de aquellos tiempos. Afortunadamente la Biblioteca de Autores Cristianos está editando, bajo la dirección del gran investigador y eminente profesor de la Pontificia de Salamanca Dr. Don Antonio García y García, la colección de todos los Sínodos celebrados en las diversas diócesis españolas. Nos referimos al «Synodicon Hispanum» ${ }^{66}$. Todavía no se ha editado el correspondiente al antiguo Reino de Valencia. Es una obra monumental, que ha supuesto y está exigiendo un enorme trabajo, y que ofrece un abundante material casi siempre inédito. Se ha convertido en una obra absolutamente indispensable para todo aquel que quiera realizar una seria investigación de la España de casi la mitad del siglo XVI al XVIII.

65 Así en el libro $X$, cap. X, que trata «De multarum seu poenarum applicatione seu destinatione...». La otra cita la encontramos en el libro XIII, cap. I, num. 13, en donde recuerda que «...licere Episcopo, ad eumque pertinere cogere Synodum Dioecesanum absque consensu et consilio Capituli. In ea autem Constitutiones eumdem Episcopum edere et promulgare posse, absque consensu et approbatione cleri; debere tamen requirere consilium Capituli, tametsi illud sequi non teneatur, praeterquam in quibusdam casibus a iure expressis»; cita expresamente y recoge la respuesta dada por la Congregación al Obispo de Orihuela.

66 Hasta ahora hay ya cinco volúmenes publicados, I Galicia, II Portugal. III Astorga, León y Oviedo. IV Ciudad Rodrigo, Salamanca y Zamora. Y el V, Extremadura: Badajoz, Coria-Cáceres y Plasencia, Madrid 1990. Se continúa con la preparación y futura edición de todos lo Sínodos. 